\title{
EPIDEMIOLOGICAL ASPECTS OF HEPATOCELLULAR CARCINOMA IN A REFERRAL CENTER OF MINAS GERAIS, BRAZIL
}

\author{
Fernanda Maria Farage OSÓRIO'1, Gabriel Martin LAUAR', \\ Agnaldo Soares LIMA ${ }^{2,3}$, Paula Vieira Teixeira VIDIGAL ${ }^{4}$, \\ Teresa Cristina Abreu FERRARI ${ }^{1,2}$ and Claudia Alves COUTO', ${ }^{1,2}$
}

\begin{abstract}
Context - Studies on epidemiology of hepatocellular carcinoma and modalities of therapy used to treat this condition are scarce in Brazil. Our aim was to characterize hepatocellular carcinoma according to etiology of the underlying chronic liver disease, and treatment modalities, in a referral center in Brazil. Methods - All cases of hepatocellular carcinoma registered in the Department of Pathology during a 12-year period (1998-2010) were included. Demographic data, etiology of the underlying liver disease and treatment performed were collected. Results - This case series included 215 patients, mean age 57.3 ( \pm 14.1$)$ years, 164 (76.2\%) male. Virus C and virus B infection were detected in $88(43 \%)$ and $47(23 \%)$ patients, respectively. Ethanol abuse alone or combined with other etiologies was identified in $64(32 \%)$ individuals. Schistosomiasis was found in $18(9 \%)$ patients. Liver transplantation was the treatment of choice in $112(51 \%)$ patients. This procedure was more frequently performed in hepatitis $\mathrm{C}$ virus-related hepatocellular carcinoma (70\%) than B virus-related hepatocellular carcinoma (17\%). Tumor resection was performed in $40(18 \%)$ individuals, ethanol injection or thermo ablation in $18(14 \%)$, and chemoembolization in $14(7 \%)$. In $40(19.4 \%)$ patients no treatment was performed and this percentage remained constant over the years. Conclusions - Chronic hepatitis C, followed by ethanol abuse and chronic hepatitis B were the leading causes of underlying chronic liver disease associated with hepatocellular carcinoma. The results show a trend of increasing incidence of hepatocellular carcinoma; however, the proportion of untreated patients remained constant over the analyzed period.
\end{abstract}

HEADINGS - Hepatocellular carcinoma, epidemiology. Minas Gerais, Brazil.

\section{INTRODUCTION}

Primary liver cancer is the sixth most common cancer worldwide and the third cause of cancer related mortality ${ }^{(8)}$. Hepatocellular carcinoma (HCC) accounts for $85 \%$ to $90 \%$ of the primary liver cancers ${ }^{(5)}$. Despite the advances in the different modalities of HCC treatment including liver transplantation (LT), surgical resection and locoregional therapies, up to $70 \%$ of $\mathrm{HCC}$ patients present with advanced disease and will not benefit from these procedures ${ }^{(14)}$. At present, only one chemotherapeutic antiangiogenic drug is available for advanced disease. Overall, men are consistently more affected than women and $75 \%$ to $80 \%$ of the cases are attributed to persistent hepatitis $\mathrm{B}$ virus (HBV) or hepatitis $\mathrm{C}$ virus (HCV) infection ${ }^{(2)}$.
Although previous epidemiologic studies suggest that HCC prevalence in Brazil is low ${ }^{(3)}$, current data on its epidemiology and major treatments modalities employed are still lacking. The aim of this study was to characterize the profile of $\mathrm{HCC}$ patients from a single public referral center in Belo Horizonte, MG, Brazil, according to the etiology of the underlying chronic liver disease (CLD), demographic data and treatment modalities to which they were submitted.

\section{METHODS}

All $(n=4,503)$ liver specimens reports registered in the Department of Pathology and Legal Medicine, School of Medicine, Universidade Federal de Minas Gerais, from December 1998 to December

Declared conflict of interest of all authors: none

${ }^{1}$ Department of Internal Medicine, Faculty of Medicine, Federal University of Minas Gerais; ${ }^{2}$ Alfa Gastroenterology Institute, University Hospital, Federal University of Minas Gerais; ${ }^{3}$ Department of Surgery, Faculty of Medicine, Federal University of Minas Gerais; ${ }^{4}$ Department of Pathology and Legal Medicine, Faculty of Medicine, Federal University of Minas Gerais, Belo Horizonte, MG, Brazil.

Correspondence: Dr. Cláudia Alves Couto - Faculdade de Medicina, Departamento de Medicina Interna - Av. Prof. Alfredo Balena, 190 - $30130-100$ - Belo Horizonte, MG, Brazil. E-mail: cacouto@uol.com.br 
2010 , were reviewed. The liver samples were obtained by percutaneous needle biopsy, surgery or explanted liver. Our institution protocol follows the International Working Party recommendations for HCC diagnosis ${ }^{(10)}$. Using the following terms to select the stored reports: primary liver cancer, hepatocarcinoma, hepatocellular carcinoma and epithelial neoplasia, 240 cases were identified as possible HCC. Cases of epithelial neoplasia and inconclusive reports were submitted to immunohistochemical staining for diagnosis confirmation. Patients with definite HCC $(\mathrm{n}=218)$ by histological examination or immunohistochemistry were included in the database. Three cases of the fibrolamelar type were excluded from the analyses.

Data regarding gender, age, etiology of the underlying CLD and type of HCC treatment were collected from the medical charts of each patient. No histological review of given diagnoses was performed. The diagnosis of HBV was accepted when hepatitis B surface antigen (HBsAg) or HBV-DNA was positive. In one case, isolated HBV core antibody (anti-HBc) was detected and for analysis purposes it was included in the HBV group as other etiologies were exhaustively excluded. HCV infection was considered to be the cause of CLD when HCV-DNA and/or HCV antibody (anti-HCV) were detected.

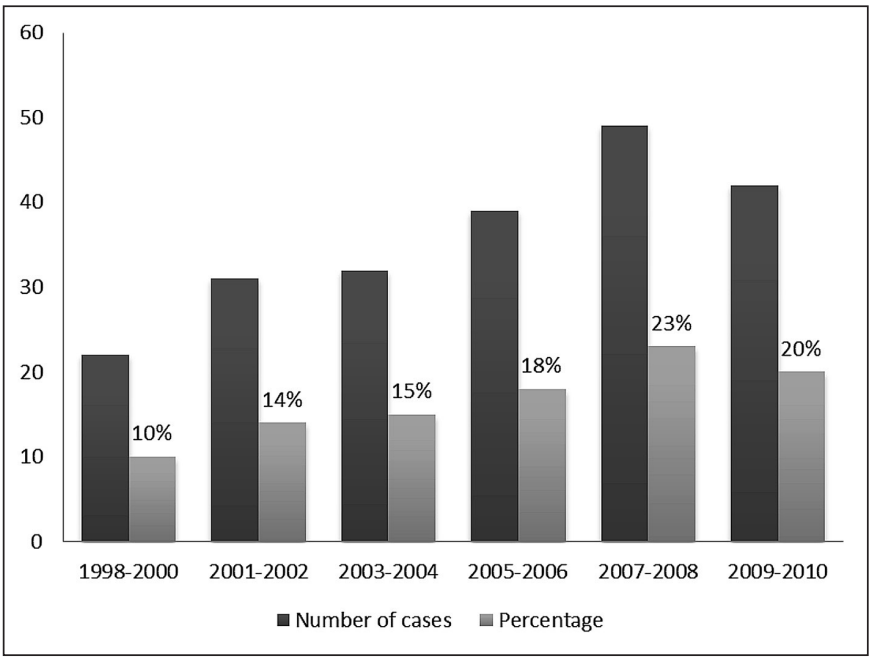

FIGURE 1. Number of new HCC diagnosed from 1998 a 2010
This study was approved by the local Ethics Committee.

Data were summarized as the means \pm standard deviation (SD) or proportions. Statistical analysis was carried out using JMP software, version 9.0 (S.A.S.).

\section{RESULTS}

Two hundred fifteen cases were included, $164(76.2 \%)$ of them were male and $51(23.7 \%)$, female. The mean age was $57.3( \pm 14.1)$ years and the medians, 57.9 years and 59.8 years for males and females, respectively. We verified a progressive increase in the number of newly diagnosed cases over the last 12 years at our Institution (Figure 1).

The major causes of CLD were viral hepatitis infection. Figure 2 shows the distribution of the major CLD through the period of the study. HCV, the most common among all etiologies, was present in $88(44 \%)$ patients, and HBV, in $47(23.5 \%)$. Ethanol consumption, alone or combined with another cause for the liver damage, was observed in $64(32 \%)$ cases. Interestingly, $18(9 \%)$ patients had schistossomiasis. From those, in six cases, schistossomiasis was the unique identified liver disease. In 15 patients, evaluation for cirrhosis etiology was not completed due to loss of follow-up.

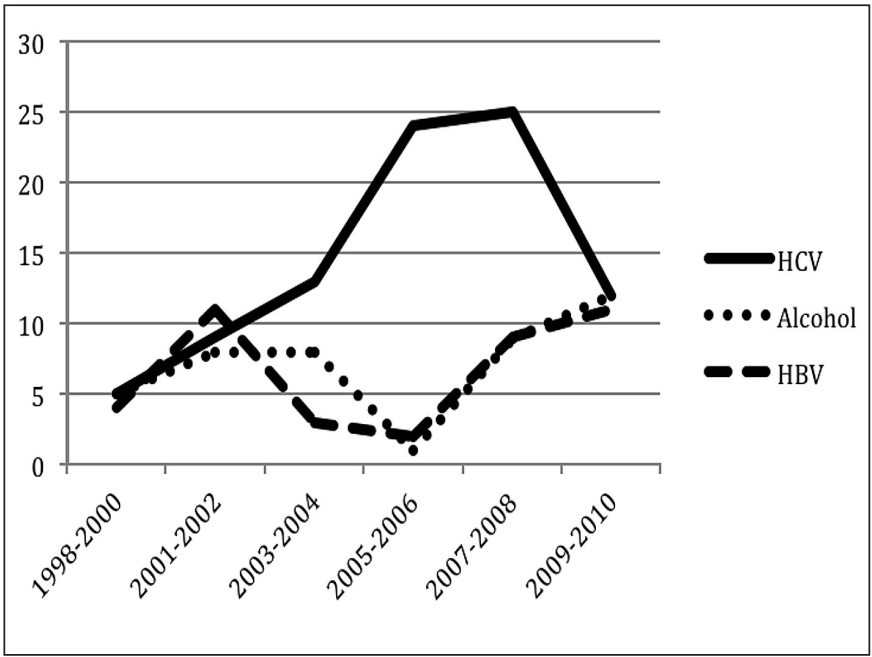

FIGURE 2. Distribution of the major CLD through the observed period

TABLE 1. Etiology of the underlying chronic liver disease of the hepatocellular carcinoma (HCC) cases and its characterization according to sex and age of the patients and HCC treatment

\begin{tabular}{|c|c|c|c|c|c|}
\hline Etiology & $\begin{array}{l}\text { Male sex } \\
\mathrm{n}(\%)\end{array}$ & $\begin{array}{c}\text { Age mean } \\
( \pm \mathrm{SD}) \text { (years) }\end{array}$ & $\begin{array}{c}\text { Treated patients } \\
\mathrm{n}(\%)\end{array}$ & $\begin{array}{c}\text { Transplantation } \\
\text { n (\%) }\end{array}$ & $\begin{array}{l}\text { Surgery } \\
\mathrm{n}(\%)\end{array}$ \\
\hline $\mathrm{HCV}$ & $59(67.1 \%)$ & $57.6( \pm 1,4)$ & $80(93 \%)$ & $61(70.9 \%)$ & $14(67.1 \%)$ \\
\hline Ethanol & $43(100 \%)$ & $57.3( \pm 1.9)$ & $25(81.4 \%)$ & $25(58.1)$ & $5(11.6 \%)$ \\
\hline $\mathrm{HBV}$ & $37(92.5 \%)$ & $55.3( \pm 2.1)$ & $25(64.1 \%)$ & $8(20.5 \%)$ & $11(28.2 \%)$ \\
\hline Cryptogenic/NASH & $9(60 \%)$ & $60.3( \pm 3.3)$ & $13(86.7 \%)$ & $10(66.7 \%)$ & $3(20 \%)$ \\
\hline Other CLD & $1(14.3 \%)$ & $35.8( \pm 4.9)$ & $5(71.4 \%)$ & $5(71.4 \%)$ & $0(0.0 \%)$ \\
\hline Schistosomiasis & $6(85.7 \%)$ & $63.9( \pm 4.9)$ & $4(57.1 \%)$ & $2(28.6)$ & $2(28.6 \%)$ \\
\hline
\end{tabular}

HCV: hepatitis C virus; HBV: hepatitis B virus; CLD: chronic liver disease; HCC: hepatocellular carcinoma; SD: standard deviation; NASH: non-alcoholic steatohepatitis 
Table 1 shows the etiology of the underlying CLD according to gender and age of the patients and treatment performed. The etiologies of the CLD were grouped as follows: 1) $\mathrm{HCV}$ and HCV combined with other CLD; 2) HBV and HBV combined with other CLD; 3) ethanol abuse; 4) cryptogenic cirrhosis and NASH; 5) other CLD which included two cases of autoimmune disease, one of hemochromatosis, two of the Budd Chiari syndrome, one of Caroli's disease, one of primary biliary cirrhosis and two cases of tyrosinemia; and 6) shistosomiasis. The male sex was more prevalent in all groups, except in the autoimmune and metabolic group. All individuals with cirrhosis due to ethanol abuse were men.

The majority of treated patients underwent LT (112 patients; $54.4 \%$ ). Prior to LT, one individual was submitted to radiofrequency ablation (RFA) and three, to transarterial chemoembolization (TACE). Cancer resection was performed in $38(18.4 \%)$ patients and 3 of them underwent percutaneous ethanol injection (PEI) prior to surgery. PEI was performed in a total of $14(6.8 \%)$ patients. TACE or RFA alone or in combination with other therapy modalities were performed in a total of $14(6.8 \%)$ and $4(2 \%)$ individuals, respectively. Other modalities of treatment such as chemotherapy, including sorafenib, were uncommonly performed (8 patients; 3.9\%). Twelve patients lost the follow-up and were excluded from the treatment analysis. A large number of individuals (40 individuals; 19.4\%) did not undergo any form of treatment. Figure 3 shows frequency of treated cases and major treatment modalities performed over the years.

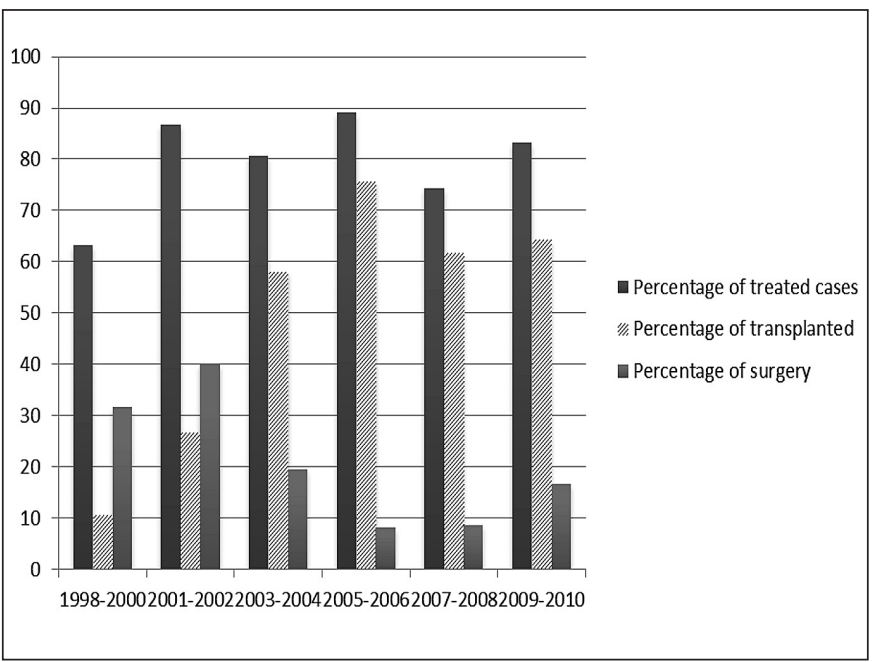

FIGURE 3. Frequency of treatment and treatment modalities over the years

\section{DISCUSSION}

Recent epidemiologic studies have highlighted that HCC incidence rates have been changed over time ${ }^{(15)}$. In the United States, for example, from 1975 to 2005 the overall age-adjusted incidence tripled ${ }^{(1)}$. Our findings also show a tendency of increasing rates, as $60.5 \%$ of the HCC cases were diagnosed during the last 6 years of this case series. This observation may reflect an actual increase in HCC; however, it could also be explained, at least partially, by improvements in diagnosis methods and by the impact of implementation of the Model of End-Stage Liver Disease score (MELD score), which led to higher rates of HCC-related LT. Furthermore, it is important to emphasize that the studied population comes from the pathology data-base, thus it comprised all HCC biopsy-proven cases, but tumors diagnosed only on the bases of imaging methods whose patients were not subsequently submitted to surgical procedures, including LT, were not included in this case series. This fact may have underestimated $\mathrm{HCC}$ numbers in our center.

In this case series, the ratio male to female was 3.2:1. Overall, $\mathrm{HCC}$ is more than twice as common in males than in females ${ }^{(11)}$. The mean age found was 57.3 years, which is similar to the mean age observed in China, but much lower than those found in European and North American. In lowrisk populations, the highest incidence of $\mathrm{HCC}$ is among individuals aged 75 years or older ${ }^{(6)}$.

The first Brazilian national survey, reported in 1997, showed a higher prevalence of HCC in the male sex, and viral hepatitis, specially due to B virus infection, as the predominant etiology of the underlying $\mathrm{CLD}^{(9)}$. However, from 2004 to 2009, another national survey was conducted to update those data and showed a somewhat different profile ${ }^{(4)}$. Our findings are in agreement with the data reported in this more recent survey, as it showed that $\mathrm{HCV}$ replaced $\mathrm{HBV}$ as the most frequent cause of liver cirrhosis and HCC.

A large number of the patients with $\mathrm{HCC}$ were not treated due to advanced disease at the time of diagnosis. Over the years of the study, there was no significant difference regarding the proportion of patients treated, which suggests that in spite of the improvements in imaging methods to diagnose HCC, we are still postponing its diagnosis. This finding highlights the importance of increasing surveillance in Brazilian patients at risk of developing HCC. Surveillance with abdominal ultrasound for detecting $\mathrm{HCC}$ in patients with liver cirrhosis increases survival of the individuals with $\mathrm{HCC}$ as this approach allows earlier tumor detection, enabling application of radical therapies to accurately selected patients, and efficient management of complications of the liver disease ${ }^{(13)}$.

According to current guidelines, LT is the first-line modality of therapy for patients with single tumors less than $5 \mathrm{~cm}$ or 3 or less nodules with $3 \mathrm{~cm}$ or less not suitable for resection ${ }^{(7)}$. In our study, among the individuals who were treated, LT was the most commonly therapeutic approach; and, the number of transplanted individuals was much higher than previously reported ${ }^{(4)}$. This could be a bias of selection, as our Institution is one of the largest LT referral center in Brazil. As expected, most LT (55.4\%) were due to HCV-related $\mathrm{HCC}$ while $\mathrm{HBV}$ accounted for only $7.2 \%$. TACE, RFA and PEI were uncommonly performed.

Although in patients with advanced HCC, sorafenib has been proved to extend survival rates ${ }^{(12)}$, in this case series, only 
a few individuals received this medication due to restrictions to obtain the drug from the public health system.

In the group of patients described herein, the advanced stage of the disease, along with the characteristics of our institution and the specific expertise of the transplantation team, certainly, were determinants of treatment modalities. Future studies and investigations in other regions of Brazil are needed to show the trends in diagnosing and treating $\mathrm{HCC}$ in Brazilian patients.

\section{CONCLUSIONS}

In this 12-year case series, viral hepatitis was the main CLD associated with HCC, and liver transplantation, the major treatment modality used to treat this condition. It is noteworthy that a large proportion of patients, throughout the study period, did not receive any treatment due to late diagnosis. Further studies are required to better characterize the different features of $\mathrm{HCC}$ in the Brazilian population.

Osório FMF, Lauar GM, Lima AS, Vidigal PVT, Ferrari TCA, Couto CA. Aspectos epidemiológicos do carcinoma hepatocelular em centro de referência de Minas Gerais. Arq Gastroenterol. 2013,50(2):97-100

RESUMO - Contexto - Estudos sobre epidemiologia do carcinoma hepatocelular e terapias utilizadas em seu tratamento são escassos no Brasil. O objetivo foi caracterizar o carcinoma hepatocelular quanto à etiologia da hepatopatia crônica subjacente e modalidades terapêuticas empregadas, em um centro de referência no Brasil. Método - Todos os casos de carcinoma hepatocelular registrados no Departamento de Patologia em período de 12 anos (1998-2010) foram incluídos. Dados demográficos, etiologia da hepatopatia crônica e tipo de tratamento realizado foram coletados dos prontuários. Resultado - Esta série de casos incluiu 215 pacientes, com média de idade 57,3 ( \pm 14,1) anos, 164 (76,2\%) do sexo masculino. Infecções virais C e B foram detectadas em 88 (43\%) e 47 (23\%), respectivamente. Abuso de etanol isoladamente ou associado a outras causas foi identificado em $64(32 \%)$ indivíduos. Esquistossomose foi encontrada em 18 (9\%) indivíduos. Transplante hepático foi o tratamento de escolha em $112(51 \%)$ pacientes. Esse procedimento foi mais frequentemente realizado em carcinoma hepatocelular relacionado com hepatite $\mathrm{C}(70 \%)$ do que hepatite $\mathrm{B}$ (17\%). Ressecção cirúrgica foi realizada em 40 (18\%) indivíduos, alcoolização ou termo-ablação em 18 (14\%) e quimioembolização em 14 (7\%). Em $40(19,4 \%)$ pacientes nenhum tratamento foi empregado e esta porcentagem permaneceu constante ao longo dos anos do estudo. Conclusões - Hepatite viral C seguida de abuso de etanol e hepatite viral B foram as causas de hepatopatia crônica mais frequentemente associadas ao carcinoma hepatocelular. Os resultados mostram tendência a aumento da incidência do carcinoma hepatocelular; no entanto, a proporção de pacientes não-tratados permaneceu constante ao longo dos anos analisados.

DESCRITORES - Carcinoma hepatocelular, epidemiologia. Minas Gerais, Brasil.

\section{REFERENCES}

1. Altekruse SF, McGlynn KA, Reichman ME. Hepatocellular carcinoma incidence, mortality, and survival trends in the United States from 1975 to 2005 . J Clin Oncol. 2009;27:1485-91.

2. Bosch FX, Ribes J, Díaz M, Cléries R. Primary liver cancer: worldwide incidence and trends. Gastroenterology. 2004;127(5 Suppl 1):s5-s16.

3. Bosch FX, Ribes J, Cléries R, Díaz M. Epidemiology of hepatocellular carcinoma. Clin Liver Dis. 2005;9:191-211.

4. Carrilho FJ, Kikuchi L, Branco F, Goncalves CS, Mattos AA, Brazilian HCC Study Group. Clinical and epidemiological aspects of hepatocellular carcinoma in Brazil. Clinics (São Paulo). 2010;65:1285-90.

5. El-Serag HB, Rudolph KL. Hepatocellular carcinoma: epidemiology and molecular carcinogenesis. Gastroenterology. 2007;132:2557-76.

6. El-Serag HB. Epidemiology of viral hepatitis and hepatocellular carcinoma. Gastroenterology. 2012;142:1264-73.e1.

7. European Association for the Study Of The Liver; European Organisation for Research and Treatment of Cancer. EASL-EORTC Clinical practice guidelines: management of hepatocellular carcinoma. J Hepatol. 2012;56:908-43.

8. Ferlay J, Shin HR, Bray F, Forman D, Mathers C, Parkin DM. Estimates of worldwide burden of cancer in 2008: GLOBOCAN 2008. Int J Cancer. 2010;127:2893-917.

9. Gonçalves CS, Pereira FE, Gayotto LC. Hepatocellular carcinoma in Brazil: report of a national survey. Rev Inst Med Trop São Paulo. 1997;39:165-70.
10. International Working Party. Terminology of nodular hepatocellular lesions. Hepatology. 1995;22:983-93.

11. Jemal A, Bray F, Center MM, Ferlay J, Ward E, Forman D. Global cancer statistics CA Cancer J Clin. 2011;61:69-90.

12. Llovet JM, Ricci S, Mazzaferro V, Hilgard P, Gane E, Blanc JF, de Oliveira AC, Santoro A, Raoul JL, Forner A, Schwartz M, Porta C, Zeuzem S, Bolondi L, Greten TF, Galle PR, Seitz JF, Borbath I, Häussinger D, Giannaris T, Shan M, Moscovici M, Voliotis D, Bruix J; SHARP Investigators Study Group. Sorafenib in advanced hepatocellular carcinoma. N Engl J Med. 2008;359:378-90.

13. Sangiovanni A, Del Ninno E, Fasani P, De Fazio C, Ronchi G, Romeo R, Morabito A, De Franchis R, Colombo M. Increased survival of cirrhotic patients with a hepatocellular carcinoma detected during surveillance. Gastroenterology. 2004; 126:1005-14.

14. Thomas MB, Jaffe D, Choti MM, Belghiti J, Curley S, Fong Y, Gores G, Kerlan R, Merle P, O'Neil B, Poon R, Schwartz L, Tepper J, Yao F, Haller D, Mooney M, Venook A. Hepatocellular carcinoma: consensus recommendations of the National Cancer Institute Clinical Trials Planning Meeting. J Clin Oncol. 2010;28:3994-4005.

15. Venook AP, Papandreou C, Furuse J, de Guevara LL. The incidence and epidemiology of hepatocellular carcinoma: a global and regional perspective. Oncologist. 2010;15(Suppl 4):5-13.

Received 13/1/2013. Accepted 15/2/2013. 